\title{
The Influence of Demography, Social Environment and Financial Self-Efficacy toward Saving Behavior
}

\author{
Dewi Rahmawati \\ Universitas Negeri Surabaya \\ Surabaya, Indonesia \\ dewirahmawati.mk@gmail.com
}

\author{
Nadia Asandimitra \\ Universitas Negeri Surabaya \\ Surabaya, Indonesia \\ nadiaharyono@unesa.ac.id
}

\begin{abstract}
This study aims to examine the influence of demography, social environment, and financial selfefficacy on the saving behavior. Demographic variables consist of gender, age, education level, income, marital status, and number of dependents. Meanwhile, the social environment variable consists of parents and peers. The sample was 220 people in Surabaya. Data were collected using questionnaires. The analysis technique used was multiple linear regression. The result of this analysis showed that in the demographics, only income that have positive effect on saving behavior. The social environment variables explained that parents give positive effect and peer has no effect on saving behavior. Meanwhile, financial self-efficacy has a positive effect on saving behavior.
\end{abstract}

Keywords—demography; social environment; financial self-efficacy; saving behavior.

\section{INTRODUCTION}

Indonesian government has implemented various ways to increase economic growth. For large infrastructure projects, the government has prepared costs through the State Budget (APBN). However, for investments in the medium and small sectors, it is undeniable that funds are needed. For this sector then the government needs support from the banking industry. Therefore, the government encourages people to love saving so that it helps the banking industry to collect deposits that can be used by banks to channel credit to the small and medium sectors. This credit channeling can drive the country's economy.

A study conducted by Jagadeesh [1] shows that there is a relationship between public savings and economic growth. Savings from the community can be a source of investment. Therefore, the government must adopt an appropriate approach to encourage savings and economic growth.

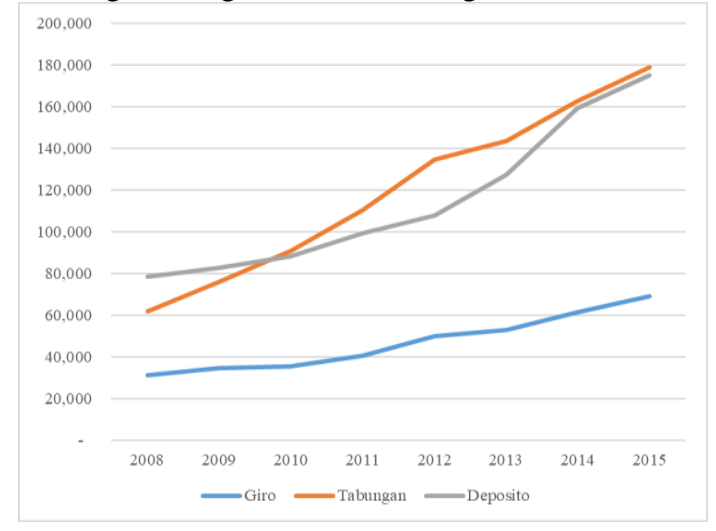

Figure 1. Total Composition of TPF for Commercial Banks in East Java in 2011 - 2015 (In Billions of Rupiah) Source: Financial Services Authority (data processed by the author, 2016)

Based on Figure 1, it is known that from 2008 to 2015 the number of public savings in East Java increased every year. This shows that East Java's public trust in banking is increasing because of the increasing number of deposits in banks. In 2010 towards 2011 there was a shift in the savings of the people of East Java, who were initially larger on the savings side, turning into deposits in the form of deposits. In fact, deposit rates are indeed greater than savings rates. However, the changes that took place between 2009 and 2010 coincided with the decline in deposit rates as shown in Table 1. This shows that people who save money in banks are not only influenced by interest rates. 
TABLE 1. AVERAGE INTEREST RATE OF COMMERCIAL BANK THIRD PARTY FUNDS FOR 2008-2015

\begin{tabular}{clllllllll}
\hline No. & DPK & $\mathbf{2 0 0 8}$ & $\mathbf{2 0 0 9}$ & $\mathbf{2 0 1 0}$ & $\mathbf{2 0 1 1}$ & $\mathbf{2 0 1 2}$ & $\mathbf{2 0 1 3}$ & $\mathbf{2 0 1 4}$ & $\mathbf{2 0 1 5}$ \\
\hline 1 & Saving & 3.11 & 2.79 & 2.92 & 2.44 & 1.91 & 2.01 & 2.02 & 1.99 \\
2 & Deposit & 10.34 & 9.54 & 7.65 & 6.87 & 6.05 & 7.14 & 8.76 & 8.58 \\
3 & Giro & 2.90 & 2.39 & 2.23 & 2.41 & 2.12 & 2.12 & 2.31 & 2.19 \\
\hline \multicolumn{1}{c}{$\begin{array}{l}\text { Source: Financial } \\
\text { author, 2016) }\end{array}$} & Services & Authority (data processed by the & & & & &
\end{tabular}

Saving money in a bank either in the form of savings or deposits is also a form of direct investment from investors [2]. In making investment decisions, investors need information which are important factors as a basis for determining investment choices. From the available information, then they form a decision-making model in the form of investment assessment criteria to enable investors to choose the best investment among available investment alternatives. Financial investors do not always use statistical tools as a tool used to process data in the process of consuming financial products. Lubis [3] states that there are other factors that can influence investment decisions that can be seen from demographic variables, such as: gender (gender), age, income level, and level of education. Demographic factors consisting of gender, age, education level, income, marital status, and number of dependents are identified as one of the factors that influence a person in saving behavior.

\section{LITERATURE REVIEW}

\section{A. Planned Behaviour Theory}

The theory underlying the model developed in this study was based on the Planned Behavior Theory (TPB) proposed by Ajzen [4]. This theory explains that some people do certain behaviors since they have an intention to do it. The intention is determined by three factors including behavior, subjective norm, and perception about behavior control. Such behavior is defined as an evaluation towards the behaviors of the individuals, while the behavior control perceived refers to those who believe in their ability in carrying out the behaviors.

The Planned Behavior Theory has been widely applied in order to understand the ways to show reactions. This theory is one of social psychology theory that predicts human behaviors. The main reason of the decision making is the result of reasoning process which is influenced by behaviors, norms, and behavior control of Chatzisarantis [5]. Furthermore, Sommer [6] says that human behavior is caused by various different reasons and possibilities which means that somebody's belief towards the consequence of behaviors, belief towards the expectation of other people, and any other factors that might avoid the behaviors. This theory shows that somebody's background such as gender, age, experience, knowledge, will affect his belief towards the things that finally affect his behavior.

In dealing with the objectives of this study, the two factors of behavior and perception about behavior control were used in order to evaluate the perception of gender, age, education level, income, marital status, and the amount of the burden can predict the people's behavior of saving money. Meanwhile, on the other side, subjective norm refers to the condition in which social pressure affects people's intention to save money. Therefore, it is used to explain that the influence of social environment such as parents and peers will affect their behavior of saving money.

\section{B. Life Cycle Hypothesis Theory}

Life-Cycle Hypothesis (LCH) is an economic theory that deals with somebody's shopping and saving behaviors along his or her life. This concept is developed by Modigliani [7]. LCH regards the basic needs of individual consumption fall upon constant percentage from the income the person has along their life that has been anticipated previously. For example, for those who saves money for their retired period, they, who have fixed income already, will spend all their income when they receive it. Then, $\mathrm{LCH}$ divides the individuals into 3 age stages covering young age stage, working age stage, and retired age stage Zwane [8]. LCH concludes that the tendency of the consumption is, in average, is bigger than the young age stage since they borrow the income that actually they will get in the future and in the retired age stage because they use their savings. Meanwhile, the individuals in working age stage have a bigger tendency to save money compared to consumption. Moreover, in this stage, their income is higher than the other stages Minh [9].

\section{Social Cognitive Theory}

In social cognitive perspective, individuals are seen to have proactive ability and self-control rather than only having reactive behaviors and the control by biological and environmental power. In addition, individuals are also believed to have self-beliefs that enable them to train and measure their control of their mind, feeling, and behaviors. Bandura [10] shows that individuals make and develop selfperception upon the ability to be the instrument for the objectives they are chasing and the control of the things in their environment. The foundation of Bandura's perception towards the reciprocal determinism deems that: (a) the personal factor in the form of cognition, affection, and biological events, (b) behaviors, (c) the influence of 
environment makes the interaction becomes the result of triadic reciprocality. The action-reaction characteristics in human, based on social cognitive theory, enables them to develop their therapy and counseling business which are oriented to the personal, environment, behavior factors.

Social cognitive theory is rooted on the view about human agency which explains that individuals are agents that proactively participate in their own environment and they are able to create something dealing with their behaviors. The key of the understanding of the agency is the fact that, among the personal factors, the individuals have self-beliefs which enable them to train controlling their mind, feeling, and behaviors that "what they think, believe, and feel, affects their behaviors." Dealing with the objective of the study, their social cognitive theory is used to explain the perception of financial self-efficacy which affects society's behavior in saving money Lown [11] and Asandimitra [12]

\section{RESEARCH METHODS}

The population in this study was in line with the number of the people in Surabaya. The scope and limit of the population dealt with the people in Surabaya whose age are between 15-64 years old.

The number of the sample involved in this study was determined through non-probability sampling method with judgemental snowball sampling technique. The variables used in this study were dependent variable and independent variable. The dependent variable (Y) in this study was the behaviors of saving money. Such behavior used in this study was measured through the statements of Sirine [13]. The independent variable in this study was gender $\left(\mathrm{X}_{1)}\right.$, the measurement of which was based on the research conducted by Kostakis [14]; age $\left(\mathrm{X}_{2}\right)$ which was measure through scoring based on Popovici's [14] study; education level $\left(\mathrm{X}_{3}\right)$ which was measured scoring based on the study done by Margaretha [16]; income $\left(\mathrm{X}_{4}\right)$ which was measured through scoring based on the study carried out by Ida [17]; marital status $\left(\mathrm{X}_{5}\right)$, the measurement of which was based on the study done by Kostakis [14]; amount of burden $\left(\mathrm{X}_{6}\right)$, which was measured though burden ratio. Furthermore, the burden ratio can be measured through Gedela's [18] formula.

Parents $\left(\mathrm{X}_{7}\right)$ and peers $\left(\mathrm{X}_{8}\right)$ were measured by Sirine's statements [13] that have been adapted. Financial self-efficacy $\left(\mathrm{X}_{9}\right)$ in this study was measured by Farrel's statement [19].

The data collection techniques in this study used interviews and questionnaires. The interviews were conducted to find out the profile of respondents in order to be able to find the suitable respondents that meet the criteria of this research subjects, namely Surabaya residents aged 15 to 64 . The researcher distributed the questionnaires to 220 respondents. Likert scale was employed to measure the subjects' responses. The data analysis techniques in this study consisted of validity and reliability test, descriptive analysis, classical assumption test, hypothesis test, multiplelinear analysis and coefficient of determination.

\section{RESULTS}

Based on the calculation of the statistical t-test on the effect of gender, age, education level, income, marital status, dependency ratio, parents, peers, and financial self-efficacy can be seen in Table 3 as follows.

\section{TABLE 2. THE EFFECT BETWEEN VARIABLES}

\begin{tabular}{|c|l|c|c|}
\hline No. & $\begin{array}{l}\text { Independent } \\
\text { Variable }\end{array}$ & $\begin{array}{c}\text { Significant } \\
\text { Value }\end{array}$ & Result \\
\hline 1 & Gender & 0,353 & No effect \\
\hline 2 & Age & 0,757 & No effect \\
\hline 3 & $\begin{array}{l}\text { Education } \\
\text { Level }\end{array}$ & 0,868 & No effect \\
\hline 4 & Income & 0,002 & $\begin{array}{c}\text { There is an } \\
\text { effect }\end{array}$ \\
\hline 5 & Marital Status & 0,475 & No effect \\
\hline 6 & $\begin{array}{l}\text { Dependency } \\
\text { Ratio }\end{array}$ & 0,434 & No effect \\
\hline 7 & Parents & 0,000 & No effect \\
\hline 8 & Peers & 0,301 & No effect \\
\hline 9 & $\begin{array}{l}\text { Financial Self- } \\
\text { Efficacy }\end{array}$ & 0,000 & $\begin{array}{c}\text { There is an } \\
\text { effect }\end{array}$ \\
\hline
\end{tabular}

Based on Table 3 that shows the results of statistics $\mathrm{F}$ test, it can be seen that the significance value of 0.000 is less than 0.05 . Then, the regression model can be used to predict the saving behavior, or it can be said that gender, age, education level, income, marital status, dependency ratio, parents, peers, and financial self-efficacy affect the saving behavior simultaneously.

TABLE 3. THE RESULTS OF STATISTICS F TEST

\begin{tabular}{|c|c|c|c|c|c|}
\hline \multicolumn{6}{|c|}{ ANOVA $^{\mathrm{a}}$} \\
\hline Model & $\begin{array}{r}\text { Sum of } \\
\text { Squares } \\
\end{array}$ & $\mathrm{df}$ & $\begin{array}{c}\text { Mean } \\
\text { Square } \\
\end{array}$ & $\mathrm{F}$ & Sig. \\
\hline 1 Regression & 1835.156 & 9 & 203.906 & 20.257 & $.000^{\mathrm{b}}$ \\
\hline Residual & 2113.803 & 210 & 10.066 & & \\
\hline Total & 3948.959 & 219 & & & \\
\hline \multicolumn{6}{|c|}{ a. Dependent Variable: Perilaku Menabung } \\
\hline \multicolumn{6}{|c|}{ b. Predictors: (Constant), Financial Self-Efficacy, Orang Tua, } \\
\hline \multicolumn{6}{|c|}{ Dependency Ratio, Status Pernikahan, Teman Sebaya, Gender, Tingkat } \\
\hline \multicolumn{6}{|c|}{ Pendidikan, Pendapatan, Usia } \\
\hline
\end{tabular}

\section{CONCLUSION}

The results of this study revealed that there is no effect between genders on people's saving behavior in Surabaya. It is because of the family income does not only derive from men but also women. It is not only men who can earn income to fulfill the daily 
needs but also women. Women can build their careers based on what they want and when they work hard they can generate their own income.

The age variable also has no effect on people's saving behavior in Surabaya. It is young people tend to save their income for their future needs and the old people tend to save their income for their children in the form of living expenses and inheritance.

For education level variable, it is found that there is no effect between education level and people's saving behavior in Surabaya. It is because of the technological advances give a huge impact to people, that is to access various information including financial information such as savings or investment. The ease of access to the information through technology is able to improve people's saving behavior without having a higher education level.

Differe from the results of previous variables, the income variable shows the effect on people's saving behavior in Surabaya. This is due to the amount of income; the higher people's income, the higher the funds allocation will be saved.

The marital status variable does not affect people's saving behavior in Surabaya. Single people who are not married yet will start to save their income for marriage fees in the future. For married people, they will save their income for their needs in the future such as the cost of giving birth, living expenses, taking their children to school.

The dependency ratio variable also does not give any effect on people's saving behavior in Surabaya. People with few or many family members will continue to save some of their income for fulfilling their present and future daily needs.

For parents variable, there is an effect between its variable and people's saving behavior in Surabaya. Parents are responsible to create and to build the character and personality of their children. Parents should give an example and persuade their children to know the importance of saving behavior with a hope that their children will like to save their money.

In a social environment of peers, there is no effect between peers variable on people's saving behavior in Surabaya. Peers can influence someone in terms of group preferences, but still, the individual who has a control over him or herself.

Whereas for the financial self-efficacy variable, it shows that there is an effect between its variable and people's saving behavior. Someone who has self-efficacy in finance will make the right and appropriate financial decisions with high selfconfidence. Therefore, the higher value of financial self-efficacy of someone, the higher the value of saving behavior will be.

\section{REFERENCES}

[1]. D. Jagadeesh, "The Impact of Savings in Economic Growth: An Empirical Study Based on Botswana," International Journal of Research in Business Studies and Management., vol. 2, no. 9, pp. 10-21, 2015.

[2]. J.Hartono, Teori Portofolio dan Analisis Investasi Edisi Kesepuluh. Yogyakarta: BPFE-Yogyakarta, 2016.

[3]. A.N. Lubis, I. Sadalia, K.A. Fachrudin, and J.Meliza, Perilaku Investor Keuangan. Medan: USU Press, 2013.

[4]. I.Ajzen,"The Theory of Planned Behaviour," Organizational Behaviour and Human Decision Processes., vol. 50, pp. 179-211, 1991.

[5]. N.L.D. Chatzisarantis, M.S Hagger, and B. Smith, "Influence of Perceived Autonomy Support on Physical Activity Within The Theory of Planned Behaviour," European Journal of Social Psychology., vol. 37, pp. 934-954, 2007.

[6]. L.Sommer, "The theory Of Planned Behavior And The Impact of Past Behavior," The International Business \& Economics Research Journal., vol. 10, no. 1, pp. 91-110, 2011.

[7]. F.Modigliani, and A.Bumberg, "Test of The Life Cycle Hypothesis of Saving; Aggregate Implications and Taste," American Economic Review., vol. 53, no. 1, pp. 99-124, 1954.

[8]. T. Zwane, L.Greyling, and M.Maleka, "The Determinants of Household Savings in South Africa: A Panel Data Approach," International Business and Economic Research Journal, vol. 15, no. 4, pp. 209218, 2016.

[9]. N.T.Minh, N.H. Nhat, H.Nguyen, T.T Anh, P. M. Due, and L. T. Son, "Demographics and Saving Behavior of Households in Rural Areas of Vietnam: An Empirical Analysis,"Journal of Economics and Development., vol. 15, no 2, pp. 5-18, 2013.

[10]. A. Bandura, "Self-Efficacy: Toward A Unifying Theory Of Behavioral Change," Psychological Review., vol. 84, pp. 191-215, 1977.

[11]. J. M Lown, J.H Kim, M. S. Gutter, and A.T. Hunt. "Self-efficacy and Savings Among Middle and Low Income Households," Journal of Familiy and Economic Issues., vol. 36, no. 4, pp. 491-502, 2015.

[12]. N. Asandimitra and A. Kautsar, "Financial SelfEfficacy on Women Entrepreneurs

Success," International Journal of Academic Research in Business and Social Sciences., vol. 7, no. 11, pp. 293-300, 2017.

[13]. H. Sirine, and D. S. Utami, "Faktor-Faktor Yang Memengaruhi Perilaku Menabung Di Kalangan Mahasiswa," Jurnal Ekonomi dan Bisnis., vol. 19, no. 1, pp. 27-52, 2016.

[14]. I.Kostakis, "Households' Saving Behavior in Greece Corresponding Countermeasures in Financial Crisis," International Journal of Economic Practices and Theories., vol. 2, no. 4, pp. 253-265, 2012.

[15]. G.Popovici, "Understanding the Factors Affecting Savings of Dutch Households," Netspar-Network for Studies on Pensions, Aging and Retirement, Working Paper, 028., 2012.

[16]. F. Margaretha, and R.A.Pambudhi "Tingkat Literasi Keuangan Pada Mahasiswa S-1," JMK, vol. 17, pp. 76-85, 2015.

[17]. Ida, and C. Y Dwinta. "Pengaruh Locus of Control, Financial Knowledge, Income Terhadap Financial Management Behavior," Jurnal Bisnis Dan Akuntansi., vol. 12, no. 3, pp. 131-144, 2010.

[18]. S. P. R. Gedela, "Determinants of Saving Behaviour in Rural and Tribal Households: An Empirical analysis of Visakhapatnam District," International Journal of Research in Social Sciences., vol. 2, no.3, pp. 108128, 2012.

[19]. L.Farrell, T.R.L Fry, and L. Risse, "The Significance Of Financial Self-Efficacy In Explaining Women's 
Personal Finance Behaviour," Jurnal of Economic Psychology., vol. 54, pp. 85-99, 2016. 